\title{
Impact Of Structure On Team Performance
}

\author{
Incidencia de la estructura en el desempeño del equipo
}

Impacto da estrutura no desempenho da equipe

\section{Luz Esperanza Bohórquez Arévalo ${ }^{1}$ María Fernanda Rodríguez López ${ }^{2}$ Catherine Acevedo González ${ }^{3}$}

Received: December $15^{\text {th }}, 2020$

Accepted: February 05 ${ }^{\text {th }}, 2021$

Available: May $05^{\text {th }}, 2021$

How to cite this article:

L. E. Bohórquez Arévalo, M. F. Rodríguez López, C. A. González, "Impact of Structure on

Team Performance," Revista Ingeniería Solidaria, vol. 17, no. 2, 2021.

doi: https://doi.org/10.16925/2357-6014.2021.02.07

Research article. https://doi.org/10.16925/2357-6014.2021.02.07

1 Ingeniería Industrial. Facultad de Ingeniería. Universidad Distrital Francisco José de Caldas.

Email: lebohorqueza@udistrital.edu.co

ORCID: https://orcid.org/0000-00001-8401-3471

CVLAC: http://scienti.colciencias.gov.co:8081/cvlac/visualizador/generarCurriculoCv. do?cod_rh=0000401498

2 Ingeniería Industrial. Facultad de Ingeniería. Universidad Distrital Francisco José de Caldas.

Email: marialopezrodriguez685@hotmail.com

ORCID: https://orcid.org/0000-0002-8660-5005

CvLAC: http://scienti.colciencias.gov.co:8081/cvlac/visualizador/generarCurriculoCv. do?cod_rh $=0001815422$

3 Ingeniería Industrial. Facultad de Ingeniería. Universidad Distrital Francisco José de Caldas.

Email: kacevedog@udistrital.edu.co

ORCID: https://orcid.org/0000-0001-5906-5333

CvLAC: https://scienti.minciencias.gov.co/cvlac/visualizador/generarCurriculoCv.do?cod_rh=0001730339\# 


\section{Abstract}

This article is the product of research on business self-organization, developed at the Universidad Distrital Francisco Jose de Caldas from 2019 to 2020. Collective intelligence $(\mathrm{CI})$ has been viewed as an approach that enables the use of interactions between agents and, in-turn, with their environment, to increase the intelligence of the system; understood as the ability to take full advantage of distributed resources and to adapt nimbly to the changing conditions of the environment

Methodology: In the first part, the conditions that may facilitate $\mathrm{Cl}$ are explored through a review of the literature. In the second part, an experiment is designed in a micro-world environment which incorporates some of the conditions identified to facilitate the $\mathrm{Cl}$ in the structure of a team, and its performance is compared with a team that has a hierarchical structure.

Results: When teams have a structure, it facilitates $\mathrm{Cl}$, leads to greater-than-average performance, coordination effectiveness and adaptability, as well as better interaction dynamics among the members. These teams present higher levels of interaction, information flows and activity among the participants, reflected in the number of interventions and in the use of the resources offered in the game.

Conclusions: The increase in complexity that the application of $\mathrm{Cl}$ induces, gives the team a better performance in environments of increasing complexity; in contrast to teams that have structures that reduce their complexity within the hierarchical structure.

Originality: This article provides evidence regarding the incidence of roles in the performance of the company. Limitations: One of the main constraints is the virtual interaction between the participants and between them with the research team. Face-to-face interaction would allow more intensive use of affiliate links between participants.

Keywords: collective intelligence, micro-world, hierarchical structure, organizational structure

\section{Resumen}

Introducción: Este artículo es producto de una investigación sobre la autoorganización empresarial desarrollada en la Universidad Distrital Francisco José de Caldas en el período 2019-2020 partiendo de que la inteligencia colectiva (IC) se ha visualizado como un enfoque que permite a partir del aprovechamiento de las interacciones entre los agentes y de estos con el entorno, incrementar la inteligencia del sistema; entendida como la capacidad para aprovechar recursos distribuidos y adaptarse de manera ágil a las condiciones cambiantes del entorno.

Metodología: en la primera parte se exploran a partir de revisión de literatura las condiciones que pueden facilitar la IC. En la segunda parte se diseña un experimento en un ambiente de micromundo en el que se busca incorporar algunas de las condiciones identificadas para facilitar la IC en la estructura de un equipo y se compara su desempeño con un equipo que tiene una estructura jerárquica. Los micromundos son entornos altamente configurables que permiten ser explorados de manera no lineal por los usuarios (Minsky y Papert, 1971).

Resultados: los resultados generados muestran que los equipos que tienen una estructura con inductores que facilitan la IC, presentan en promedio mayor rendimiento, efectividad de coordinación y adaptabilidad, al igual que mejores dinámicas de interacción entre los integrantes. De hecho, dichos equipos presentan mayores niveles de interacción, flujos de información y actividad entre los participantes, los que se refleja tanto en la cantidad de intervenciones, como en el aprovechamiento de los recursos que el juego ofrece para aumentar la capacidad de cumplir la misión.

Conclusiones: el incremento de la complejidad que le otorga al equipo la aplicación de inductores de IC podría ser un predictor de mejores desempeños en entornos de complejidad creciente; en contraste con equipos que posean estructuras que reducen su complejidad, tal como es el caso de la estructura jerárquica. 
Limitaciones: una de las principales limitaciones es la interacción virtual entre los participantes y entre ellos con el equipo investigador. La interacción presencial permitiría aprovechar más intensamente los vínculos de afiliación entre los participantes. Además, los resultados obtenidos no son generalizables tanto por el número de equipos en los que se realiza el experimento, como por la complejidad del entorno de sistemas reales en los que se encuentran inmersos los sistemas sociales humanos.

Palabras clave: inteligencia colectiva, micromundo, estructura jerárquica, estructura organizacional

\section{Resumo}

Este artigo é produto de uma pesquisa sobre auto-organização empresarial, desenvolvida na Universidad Distrital Francisco Jose de Caldas de 2019 a 2020. A inteligência coletiva (IC) tem sido vista como uma abordagem que possibilita o uso de interações entre agentes e, girar, com seu ambiente, para aumentar a inteligência do sistema; entendida como a capacidade de tirar o máximo proveito dos recursos distribuídos e se adaptar com agilidade às mudanças nas condições do ambiente

Metodologia: Na primeira parte, as condições que podem facilitar a IC são exploradas por meio de uma revisão da literatura. Na segunda parte, é elaborado um experimento em um ambiente micro-mundial que incorpora algumas das condições identificadas para facilitar a IC na estrutura de uma equipe, e seu desempenho é comparado com o de uma equipe que possui uma estrutura hierárquica.

Resultados: Quando as equipes possuem uma estrutura, ela facilita a IC, leva a um desempenho acima da média, eficácia de coordenação e adaptabilidade, além de melhor dinâmica de interação entre os membros. Essas equipes apresentam níveis mais elevados de interação, fluxos de informação e atividade entre os participantes, refletidos no número de intervenções e na utilização dos recursos oferecidos no jogo.

Conclusões: 0 aumento da complexidade que a aplicação da IC induz, confere à equipe um melhor desempenho em ambientes de complexidade crescente; em contraste com equipes que possuem estruturas que reduzem sua complexidade dentro da estrutura hierárquica.

Originalidade: Este artigo fornece evidências sobre a incidência de funções no desempenho da empresa.

Limitações: Uma das principais limitações é a interação virtual entre os participantes e entre eles com a equipe de pesquisa. A interação face a face permitiria o uso mais intensivo de links de afiliados entre os participantes.

Palavras-chave: inteligência coletiva, micro-mundo, estrutura hierárquica, estrutura organizacional

\section{INTRODUCTION}

To date, Collective Intelligence $(\mathrm{Cl})$ has been viewed as an approach that enables, from the use of interactions among agents and between these and their environment, an increase of intelligence of the system; understood as the ability to take full advantage of distributed resources and to adapt nimbly to the changing conditions of the environment [1][2]. Intelligent systems take advantage of the information of the environment in the decision-making process. Collective intelligence increases the level of knowledge of the system, which in turn leads to a greater capacity to absorb and deal with the growing complexity of the environment. $\mathrm{Cl}$ models have been successfully 
applied in medical diagnostic processes, software development, translation of applications to different languages in a short time, among others [3][4][5][6][7][43].

The purpose of this article is to compare the response of various teams, organized through two types of structures; one hierarchical and the other marked by the presence of inductors that enable collective intelligence in the presence of sudden and unexpected events. The hierarchical structure refers to the presence of a central node (leader) who determines the decisions that are made. The team members have defined roles and functions. Meanwhile, in the teams characterized by the use of $\mathrm{Cl}$ inducers, the existence of a central controller is not considered and the decisions can be taken by all the members of the team. The $\mathrm{Cl}$ structure would take advantage of resources and possibly having a better response to unexpected events and changing circumstances, although it could also have a cost due to the absence or ambiguity in the roles and affectation in the performance of the team [17][18] [31] [37][42].

For the development of the research in the first part, the conditions that may facilitate collective intelligence are explored through a review of the literature. For this purpose, $\mathrm{Cl}$ approaches and the models of some companies that incorporate schemes, that facilitate the use of distributed resources and the adaptability to the changing conditions of the environment in their operation, are reviewed [29][30]. In the second part, an experiment is designed in which it is sought to incorporate some of the conditions identified to facilitate the $\mathrm{Cl}$ in the structure of a team and its performance is compared with a team that has a hierarchical structure. For the research, a micro-world is used, also known as functional simulations or synthetic environments. Micro-worlds are highly configurable environments that allow them to be explored in a non-linear way by users [1].

In micro-world experiments, participants not only have to choose between different alternatives, as in traditional decision-making experiments, but they must also develop alternatives to choose from, just as in problem-solving experiments [8]. These settings offer a place to become familiar with situations, perform tasks, and test hypotheses within a topic of interest. Micro-worlds allow establishing causal rather than associative relationships and rule out the effects of alternate factors [40], [41]. They preserve the basic or essential characteristics of the real world while leaving aside other aspects considered superfluous to the interests of the researcher, but without stripping away the complexity and dynamic nature of the task. The applicability of micro-worlds in research lies in the fact that it allows us to maintain the behaviors under three main factors of complexity: interconnectivity, dynamics and in-transparency. Interconnectivity emphasizes the impossibility of doing only one thing, since all events that occur in the environment must be considered by the decision maker [39]. 
The dynamics are manifested in the plurality of decisions that must be made and the interdependence thereof; decisions are made in real time and are changed by the environment and as a result of the decisions of the participants. On the other hand, in-transparency emphasizes that the current state of the system, that the participants try to control, cannot be directly checked and, on the contrary, the participants must find the state through active explorations they make in the world [8], [44].

In the present investigation, we are working with the super-fireman micro-world, which is a video game of forest fires (https://www.juegosdiarios.com/juegos/super-fireman.html). Similar micro-worlds have been used to study distributed decision making in a complex environment [9]. In this work, teams organized under two different structures must make decisions to minimize the effect of fires; for example, where to put out the fires, what resources to use/purchase, when to evacuate the population, among other decisions. The results obtained allow for a comparison of the response of the teams to sudden and unexpected events in a crisis environment.

\section{LITERATURE REVIEW}

\section{Collective Intelligence}

The notion of collective intelligence is not new. However, it is in the nineties when it begins to be mostly used to describe social phenomena and the first two books focused exclusively on this subject are published: Computer intelligence in computer-based collaboration [10], and Collective Intelligence: Mankind's Emerging World in Cyberspace [11].

To date, it is possible to find different concepts of $\mathrm{Cl}$, highlighting the complementarity and homogeneity that is presented in them. On one hand, [12] proposes that the $\mathrm{Cl}$ is a group of shared intelligence that emerges from the collaboration and competition from many human or digital entities.

According to [2], $\mathrm{Cl}$ refers to the ability to cooperate and coordinate the work of group members effectively, and it is perhaps a more relevant predictor of team performance than individual skills. In other words, having capable and intelligent individuals is not enough to achieve an intelligent organization. The $\mathrm{Cl}$ can be understood as an emerging property of the synergies between the information, the Internet and the human experts, who through the use of the Internet, learn continuously from the available information to produce new knowledge and better decisions; in comparison to the decisions that could be generated from the three elements in an isolated way [15][16]. 
The relevance of $\mathrm{Cl}$ in the performance of a team has led several researchers to seek to identify the necessary traits for a team to behave intelligently. In this regard are the works of Malone, [2] from the Massachusetts Institute of Technology (MIT), who after examining more than 250 examples of $\mathrm{Cl}$, identified blocks that they classified from the following questions: What is being done? Who is doing it? Why is it being done? And how is it being done?

Each of the blocks was called a "gene" and together they refer to the central elements of a collective system under development. The complete combination of genes associated with a specific case of collective intelligence is what the authors called the genome of the system. That is to say, in order to use the proposal of the genome in a systematic way and construct collective intelligence from this system, a comprehensive classification of the different types of genes is required.

One of the examples cited by [2], to explain the existence of the $\mathrm{Cl}$ genome, is in the case of Linux; one of the most important operating systems at the beginning of the 21st century. In this case, an "open source" software development community was generated. Here, the two basic genes are the crowd and the hierarchy or management. For this case, we find that Torvalds, who had the idea, decided that all people, should be able to access the software through the Internet and let anyone modify it. Torvalds decides on the crowd gene because he has no other choice, since he has no time or money to hire people.

Hence the question: Why would people do this? Torvalds concludes that there are enough qualified programmers in the world who could do this work collectively if properly motivated. Since he can't afford to use the money gene, he uses the love and glory genes. To do this, he sent an email, so that people could have fun writing the software as a hobby. Moreover, staying active in a project such as this would give much visibility and would become a benchmark of programming skill; therefore, status and glory for many programmers.

Finally, the question must be raised as to how they would do it; and this is where the collaboration gene comes in. Torvalds realizes that, in addition to anyone who can write a code, i.e. that there are interdependent parts, he must also make sure that each and every different part works by combining them properly and with sufficient quality. For this, he would need a Group Decision gene, so that the effort would not be divided into many versions and respects the same decisions regarding what is included and what is not. This is done from a subtype of the Group Decision gene such as Voting or Consensus, in which you can vote or debate until you agree. Ultimately, he is the one who decides or will delegate to people he trusts so he finally uses the Hierarchy 
gene. This combination of genes could be called the basic "genome" of the Linux community.

For other organizations, such as Threadless and Innocentive, the key gene is to create, followed by the hierarchy gene, which work together to make decisions in their lines of business as accurately as possible. These organizations take advantage of the gene of creation that uses the knowledge and opinions of the crowd to generate solutions and even profits for the organizations.

These businesses are designed to harvest opinions on a specific topic from specialized or non-specialized people, allowing the organization to broaden its perspective of the target market, as the case may be. After collecting all the information and applying the creation gene from the hand of the hierarchy gene, members of the organization decide what information is appropriate to solve the problem.

Another example cited by [2] is the largest online encyclopedia that the Internet has: Wikipedia. Jimmy Wales, together with other people, created this community with a clear goal, to get a crowd to create something; in this case, a free online encyclopedia. The parts that are created are mostly independent from each other, which means that the gene called collection is necessary. Anyone in the crowd can create a new article, and the collection of all those independent articles constitutes the encyclopedia.

To decide which elements created by the crowd and which elements edited by the collaboration should be kept within the collection; a decision gene is usually needed. The way to make these decisions has been to use the hierarchy gene and let Wales and a few others decide which items should be removed and which should not. However, Wales and others wanted the community members to feel that they had power and ownership over the encyclopedia and thus increase their motivation in the glory gene. In addition, they wanted to have a process that could handle a large number of articles without the need for Wales and other trusted people to have direct involvement. Due to all the above, they used the voting gene where anyone in the crowd can "nominate" an article for deletion and they can also express their opinion on whether that article should be deleted or not. For the editing of the articles they use, in addition to the collaboration gene, the Hierarchy gene, thus appointing an editor for each article who will be responsible for the consistency and quality of the article.

Nevertheless, the results of the application of the $\mathrm{Cl}$ in the performance of a team, the investigators of the MIT raise that it is necessary to consider the potential biases that can appear within the constructive and collaborative process of the $\mathrm{Cl}$ : informational biases, social biases, effect of the common knowledge, and polarization.

Informational bias refers to when opinions are not independent and are acted upon by imitation. Social biases occur when interaction with other participants distorts 
opinion through negative influences [32]. The effect of common knowledge occurs when the participant is satisfied with the information and knowledge he or she already has, and does not explore new sources [38]. Polarization is the tendency to radicalize positions regarding an issue that involves cultural, social or political values to the point of over-ideologizing it or defending positions without reasoning from evidence.

The following cases presented in this article are not cited by [9] but they have been involved in this research, due to the fact that they exhibit, in some operational activities, similar schemes to those presented by the $\mathrm{Cl}$, facilitating the use of distributed resources and adaptability to changeable environmental conditions. The cases studied in this research are: Vueltap, Rappi, Glovo and Waze.

Rappi is founded in Bogota as a platform that provides products of diverse categories that are linked, from deliveries to favors, becoming recognized as the leading company in Latin America in express courier.

The platform accessed by Rappi-tenderos (messengers), customers and suppliers (stores, restaurants, markets, etc.) serves as a bridge for the monitoring and control carried out by the expeditors (administrative agents) in the different services required. This platform is linked to Google Maps that helps to manage routes through geolocation. In addition to the data provided by the tool, the Rappi-tenderos update the states in real time in order to provide traceability of the operation and its effectiveness to each of the agents within the operation (expeditors, customers and suppliers)

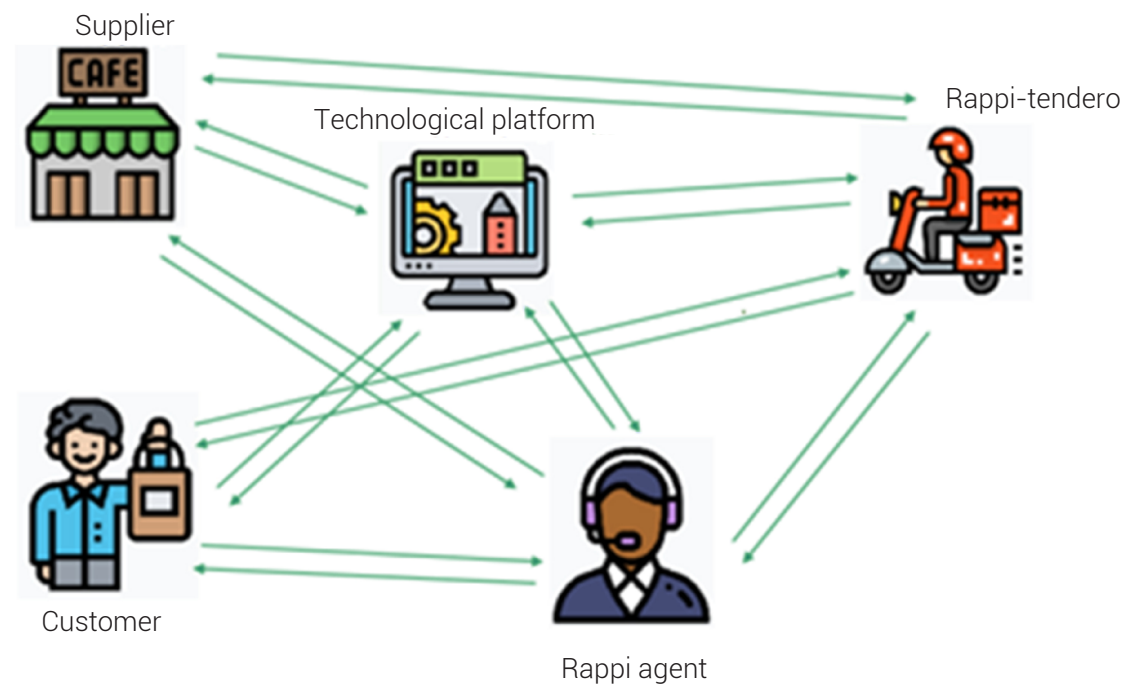

Figure 1.

Source: own work based on the interaction between agents in Rappi's model. [19] 
When a customer requires a delivery, he logs into the application with his user, makes his request, the order arrives at the restaurant's app, they prepare his order, one of the Rappi-tenderos accepts the delivery and arrives to pick up the order and then takes it to the customer. During this whole process, all the agents can communicate with each other.

Rappi is constituted by a hierarchy that starts with the CEO and under him are the heads of each area, which in turn are constituted by sub-areas and it is there where the team of each one of them is located. Each member is specialized and has specific tasks or activities that are measurable through performance indicators, linked to one of the four specific objectives that Rappi has at a given time.

Generally, each sub-area has meetings once a week to generate proposals or exchange information within the same work team. Each sub-area, and of course, each area is independent from the others. If there is a conflict to be resolved, the heads of each area meet to propose, discuss and reach agreements. Each sub-area decides what information is required within its own dashboard (boards that show relevant information) and the developers are the ones who create it depending on the requirements.

On the other hand, Vueltap is a Colombian last mile logistics and storage company. It is currently operating in cities such as Bogota, Medellin, Cali and Barranquilla. It was born as a platform that allowed anyone to access same-day delivery services. This company works as an intermediary between companies that handle e-commerce platforms, individuals who require express delivery services and Allies (messengers) who purchase the app.



Figure 2.

Source: own work based on the interaction between agents in the Vueltap model [20] 
Vueltap's main customers are companies that sell through e-commerce; these companies purchase balance through the platform for their orders. When a customer requires it, he requests the service on the platform and, through artificial intelligence, he orders the addresses of the packages; the Allies, who connect when they wish, can visualize the services that go out within a range of $5 \mathrm{~km}$ and decide whether to do it or not. This platform, as in Rappi, is linked by means of geolocalization, allowing the people in charge of the tracking to have a real time visualization of the operation.

Vueltap's objective, currently, is to provide logistics services in other cities in Colombia and to other countries within Latin America. The CEO, who directs the company, works hand in hand with the area managers to achieve the established objectives; in turn, each area is made up of a group of people who perform specific tasks [23].

For Vueltap and its technology team, it is important to constantly renew itself in order to offer its customers (internal and external) increasingly friendly ways of handling its platform. The leader of the Development area meets with the leaders of the other areas of the organization once a week to harvest information about the needs and experiences of the employees.

The development leader, from this information, creates a list of projects that will facilitate the use of the platform and the work of the different areas, ordering them by priority for their execution. To follow up on the progress of the projects and to share information, each area meets daily for 15 minutes reviewing and controlling established times and proposing solutions to limitations that arise along the way. In case there is any limitation, it is addressed to the CEO.

Meanwhile, Waze is a GPS navigation app based in Israel that provides turn-byturn navigation information, as well as all kinds of social elements such as traffic information, police controls, road works, speed cameras, among other things, because the people using the application can send information regarding this, allowing other users in the area to be informed of what they might find on the road. 


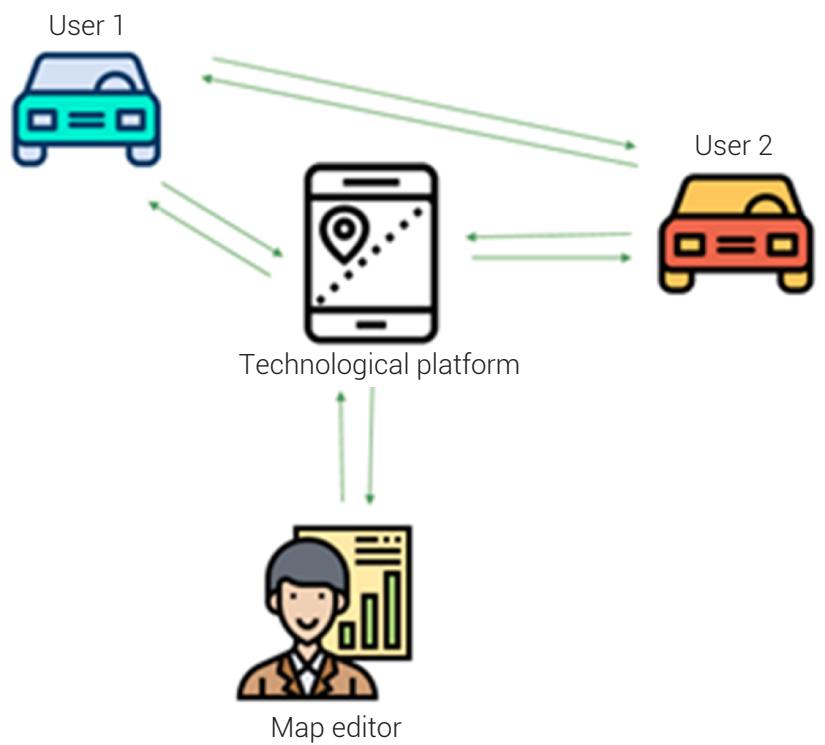

Figure 3.

Source: own work based on the interaction between agents in the Waze model [21]

The maps and navigation work thanks to the users; the more people drive with the open application, the more precise the navigation will be. By having the application open and after typing the address to which you are going to, you contribute in real time to the traffic information and other road data. In addition to this, Waze has an active community of online map editors who make sure the data in your area is up to date. When collecting information, Waze immediately analyzes it to provide other users with the optimal route to their destination, calculates the average speed, checks for errors by asking other users if what is reported does indeed exist, improves and learns the direction of turns and roads.

Waze was created with the idea that the data network connection would be active for most of the time. For all of Waze's features to work, you must have the data connection active on your mobile device. This connection provides Waze with real-time traffic information and allows the map to be updated. Without an Internet connection, the application won't be able to locate any routes or move the user around. If the Internet connection is intermittent, Waze will try to get data about traffic-related alerts and hazards from the servers, but it may not provide reliable information. Also, if Waze fails to reconnect to its servers, users will not be able to post the dangers [24].

On the other hand, we find the Spanish giant Glovo, a multi-categorical service platform which, by means of an app, connects to a friendly ecosystem between the customer, the store and the delivery people. The ecosystem begins when the 
customer requests a service through the platform designed for him, the platform takes the service and directs it to the restaurant or establishment so that it is later visible by the delivery person. By 2019 Glovo was composed of 1200 people working in their offices in Spain and more than 3600 delivery agents associated with the platform.

For Glovo, one of its main objectives is to fully meet the needs of end users and allows small businesses in cities like Madrid, Valencia, Paria and Milan to introduce and position themselves on this platform.

The information provided by the deliverer when connecting to the platform allows the Glovo team to distribute the orders and to find areas and schedules where they must get either more services or more deliverers. This guarantees constant work and coverage for the users' requests [25].

Thus, each of these examples helps to demonstrate how large and informal groups of people can collectively collaborate from an electronic means in a surprisingly effective way.

\section{METHODOLOGY}

\section{Conditions required to facilitate collective intelligence and experiment design}

Based on the literature review and the characteristics identified in the four case studies analyzed in section two, this article identifies two pre-conditions and two post-conditions in the team structure to facilitate collective intelligence (see Table 1). The pre-conditions are those that must be found before the process occurs; and the post-conditions are those that must be observed once the process occurs, and which are considered to facilitate the emergence of other $\mathrm{Cl}$ features.

Table 1. Pre- and post-conditions of the structure to facilitate $\mathrm{Cl}$ [26]

\begin{tabular}{ll}
\multicolumn{1}{c}{ PRE-CONDITIONS } & \multicolumn{1}{c}{ POST-CONDITIONS } \\
\hline Ease of interaction & Free flow of information \\
\hline Distributed control & Self-organization \\
\hline Diversity & \\
\hline
\end{tabular}

Source: own work

In all the cases reviewed, it is possible to evidence the ease with which the actors can interact. The technological platforms and, in a broad manner, the Internet, provide 
the necessary infrastructure for the interaction. The distributed control is evidenced in the absence of a central controller that determines the behavior of the system. In the cases of Vueltap, Rappi, Glovo and Waze, there is no agent that determines the allocation of resources or the priority of the service, but it is the dynamics of the interactions between the system's actors that allows the emergence of order (self-organization). The free circulation of information flow denotes the absence of restrictions in the access to information, and allows taking advantage of the space of possibilities that this can generate [31]. The actors are diverse and there is no homogeneity in their characteristics; thus, in the case of Wikipedia cited by [9], there is no specific profile for generating contributions to the network or, in the case of Rappi and other platforms, the actors are different (customers, suppliers, rappi tenderos) and although there are some features they share, there is no specific profile of each of them.

In order to verify the response generated by the teams in which the structure has the pre- and post-conditions identified, in the present experiment, it is proposed to take advantage of the bonds of affiliation existing among the participants, for example, friendship, companionship, among others. This research is based on the approaches made by different authors [13][14] who state that the number and intensity of affiliate links between team members facilitates interaction. To promote distributed control, participants should be explicitly told that there is no leader or strategist to determine decision making, and the team as a whole should be allowed to define and assign roles [33]. Additionally, the whole team can have access to all the information generated by the game (wind speed, temperature, resources used up, resources available, etc.). Diversity is facilitated to the extent that the team members do not have a specific profile (see Table 2).

The response generated by the teams with the structure that facilitates the $\mathrm{Cl}$, is compared with a hierarchical structure. For the formation of teams with a hierarchical structure, the members of each team will be chosen by the research team, in such a way that the possibility of strong affiliation ties is reduced; additionally, the research team assigns each member the role to be played (see Table 2). 
Table 2. Characteristics of the equipment designed for the experiment [27]

\begin{tabular}{|c|c|}
\hline HIERARCHICAL STRUCTURE & $\begin{array}{l}\text { STRUCTURE WITH COLLECTIVE } \\
\text { INTELLIGENCE FACTORS }\end{array}$ \\
\hline $\begin{array}{l}\text { The research team chooses the } 5 \text { members of the team } \\
\text { randomly. }\end{array}$ & $\begin{array}{l}\text { The research team asks the participants to organize } \\
\text { themselves into teams of } 5 \text { people, which facilitates } \\
\text { their organization through their affiliation networks. }\end{array}$ \\
\hline $\begin{array}{l}\text { The organizing team assigns the roles that the team } \\
\text { members will occupy: } \\
\text { - Planning chief: he is the only person who directly } \\
\text { manipulates the micro world. }\end{array}$ & $\begin{array}{l}\text { The research team suggests to the team the roles } \\
\text { through which they can be organized, and allows } \\
\text { them, if they prefer, to define and assign different } \\
\text { roles. The suggested roles are: }\end{array}$ \\
\hline \multirow{2}{*}{$\begin{array}{l}\text { Operations chief: responsible for defining the use of } \\
\text { resources such as fire trucks, helicopters and water } \\
\text { pumps. }\end{array}$} & $\begin{array}{l}\text { - Planning chief: he is the only person who directly } \\
\text { manipulates the micro world. }\end{array}$ \\
\hline & \multirow{2}{*}{$\begin{array}{l}\text { Operations chief: responsible for defining the use } \\
\text { of resources such as fire trucks, helicopters and } \\
\text { water pumps. }\end{array}$} \\
\hline $\begin{array}{l}\text { - Search and rescue chief: responsible for defining } \\
\text { the transfer of injured people to the hospital and/or }\end{array}$ & \\
\hline to safe areas as the case may be. & \multirow{2}{*}{$\begin{array}{l}\text { - Search and rescue chief: responsible for defining } \\
\text { the transfer of injured people to the hospital and/or } \\
\text { to safe areas as the case may be. }\end{array}$} \\
\hline $\begin{array}{l}\text { - Head of resources: responsible for defining the } \\
\text { need for new unit reguirements. }\end{array}$ & \\
\hline \multirow{2}{*}{$\begin{array}{l}\text { Head of communication: checks the map and } \\
\text { sends a message every } 30 \text { seconds via chat to the } \\
\text { investigation team reporting the number of fires } \\
\text { extinguished, the number of civil rescues and } \\
\text { resources used. }\end{array}$} & $\begin{array}{l}\text { - Head of resources: responsible for defining the } \\
\text { need for new unit requirements. }\end{array}$ \\
\hline & $\begin{array}{l}\text { - Head of communication: checks the map and } \\
\text { sends a message every } 30 \text { seconds via chat to the } \\
\text { investigation team reporting the number of fires } \\
\text { extinguished, the number of civil rescues and } \\
\text { resources used. }\end{array}$ \\
\hline \multirow[t]{2}{*}{$\begin{array}{l}\text { The team will have } 5 \text { minutes to plan the strategy to } \\
\text { follow. The } 5 \text { minutes are counted once the familiariza- } \\
\text { tion phase is over. }\end{array}$} & $\begin{array}{l}\text { The team will have } 5 \text { minutes to plan the strategy to } \\
\text { follow. The } 5 \text { minutes are counted once the familiariza- } \\
\text { tion phase is over. }\end{array}$ \\
\hline & $\begin{array}{l}\text { During the session, the team will be able to make di- } \\
\text { fferent consultations to a person external to the team } \\
\text { and with ample experience in the micro world. }\end{array}$ \\
\hline
\end{tabular}

Source: own work

\section{Method}

70 participants were selected from the Universidad Distrital Francisco José de Caldas. The participants are students from four different courses. The age of the participants, ranged from 21 years or so, 57\% are men and 43\% are women. The participants of two of the courses (35 people) were organized in teams of 5 people under the socalled hierarchical structure, and the participants of the remaining two courses (35 people) were organized in teams of 5 people under a structure that introduced factors that enabled the emergence of collective intelligence. In Table 1 the characteristics of the two types of structure are registered.

The experiment is carried out during the time of compulsory quarantine in the city of Bogotá due to the health emergency COVID 19. This led to the interaction between the participants and the research team, as well as the realization of the 
experiment through videoconference. Participants could communicate through video, audio and chat.

The stages that were followed for the development of the experiment were:

$\mathbf{0}$. Setting: two days before the experiment, an instrument was applied to identify the profile of the participants: age, gender, experience in strategy video games and average number of hours per day that the participant plays strategy games. Additionally, access to the micro-world was facilitated so that they could become familiar with its dynamics.

1. Team formation: In the courses defined to work the traditional structure, the research team forms the teams and assigns the roles. Meanwhile in the teams defined to work with a structure that facilitates the emergence of $\mathrm{Cl}$, the participants are asked to organize themselves in teams of 5 people and the roles are suggested that could be used for their organization. These teams have autonomy to define and assign the roles to the different members. At this stage, the recording of the game performed by the team begins.

2. Presentation: the experiment begins by informing the team of the aim of the game in the super-firefighter micro-world: "to evaluate the performance of the team with respect to the effectiveness of the strategy to put out the fires and to take advantage of the available resources". In addition, the stages to be followed and the duration of each one of them are presented. The link is sent through the videoconference chat so that all team members can access the micro-world. This stage lasts 2 minutes.

3. Tutorial: participants have 2 minutes to read the tutorial in the micro-world and interact in the demo presented there.

4. Familiarization: the team members have 1.5 minutes to interact in the first level of the micro-world.

5. Planning and role assignment: the team has 5 minutes to interact with each other and decide the strategy for decision making. In the teams with $\mathrm{Cl}$, the person in charge of communications must write in the chat of the videoconference the names and roles assigned to the different members of the team.

6. Resolution of doubts: the team has 2 minutes to solve doubts with the research team regarding the operation of the micro-world or the stages of the experiment.

7. Start of the game: the head of planning shares the screen so that it is visible to all team members.

8. Development: the team has 10 minutes to play in the micro-world. The first level takes 1.5 minutes, and the next three levels last 2 minutes each. Once the 10 minutes are over, the game stops regardless of the state of progress of the level. If, in 
this familiarization stage, the team manages to pass to the second level, the game is restarted to begin this phase and start taking the time. The tutorial is skipped.

9. Closing the game: the team is informed of the end of the experiment, and the recording of the game is closed.

10. Ending: the recordings of the game made by each team are analyzed. The analysis is done from the formation of the team, roles, through the formulation of the strategy, the performance and activity of each of the team members during the development of the game, until the closing of the micro-world.

\section{Materials}

The micro-world known as the super-fireman is used. This game has as interface field where different elements interact such as fire, a hospital, people, water and intervention units that allow for increasing the response capacity (helicopter engine, water tank, fuel tank, fire truck, large fire truck, water bomber and storms). The goal is to save lives, put out the fires, prevent them from spreading, and according to the level of the game, farms and houses should also be protected. As fires are put out, lives, houses and farms are saved; the team earns money to buy other intervention units and also earns points. The score is reset at each level, that is, all levels start at zero, although the money continues to add up at all levels, and it is only subtracted when an intervention unit is purchased.

Fires are influenced by weather conditions that change randomly (temperature, wind speed and direction) and spread in different types of vegetation and terrain, but they spread more quickly in forests. If a burned area cannot be extinguished, the fire will spread in the direction of the wind. The climatic conditions of the fire, the level of water and fuel supply of the trucks and the helicopter, the time elapsed in the level, the number of lives saved, as well as the money and the score that the team earns can be observed permanently at the top of the screen.

The micro-world consists of 6 levels that have different missions and times. Fires occur in different places so the team should check the map in order to verify where they occur. The first four levels take place in non-forest lands, and from the fifth level on, fires occur in forest lands so they can spread faster. Level 1 has the mission to save 10 people in 1.5 minutes. If the mission is completed, but time is not yet up, more fires will appear in different areas that can be extinguished and thus earn money and points. In case the fires are not extinguished, but the mission is completed, the level is won. Level 2 starts with two simultaneous fires in different areas. The mission of this level is to put out all the fires within 2 minutes. If both fires are put out before 
2 minutes, the team moves to the next level. Level 3 has the mission to put out all fires and prevent them from spreading to the farms within 2 minutes. If all fires are extinguished before 2 minutes, the team immediately moves to the next level. Level 4 has the mission to save the lives of 15 people within 2 minutes. There are two simultaneous fires that spread all the time and new fires appear. If the mission is completed within two minutes, the team immediately moves to the next level. Level 5 is intended to keep residential areas safe for 2 minutes. Two simultaneous fires occur and new fires appear in different locations on the field. This is the first level that lasts the entire time, even if the mission has been completed earlier. Level 6 has the mission to put out all the fires in 2 minutes. There are 2 farms and there are 2 simultaneous fires in different areas. The fires spread and new fires appear in different areas.

\section{Metrics}

For the design of the metrics, the study carried out by [9] is taken into account. Its purpose is to evaluate the adaptability of teams with two different structures (a functional structure with assigned roles and a non-functional structure with unassigned roles) and it is also carried out under a micro-world environment. The metrics evaluated in this research are: performance, coordination effectiveness, and adaptability.

Team performance measures the ability to put out fires in a given time interval. In this experiment, performance was measured at Level 1, since this level does not end with the fulfillment of the mission, but lasts in all cases two minutes, and during this time different fires appear. The following formula is used:

\section{Performance: $\frac{\text { number of fires extinguished }}{\text { total time of the level studied (2 minutes) }}$}

The number of fires extinguished was counted when there were no more fires in the area or in the surroundings. A team that can extinguish more fires in the same time interval will generally be able to control the threat of affecting people, homes and farms.

Coordination effectiveness was also measured in Level 1 and is evaluated in two complementary ways: score at the completion of the mission over the total time of the level (2 minutes) and money earned by the team at the completion of the mission over the total time of the level (2 minutes). The formulas are as follows: 
coordination effectiveness: $\frac{\text { score at the completion of the mission }}{\text { total time of the studied level (2 minutes) }}$ coordination effectiveness: $\frac{\text { money earned by completing the mission }}{\text { total time of the studied level (2 minutes) }}$

The score and money earned increase as the team saves lives, homes and farms, and it is evidence of the ability to leverage the resources available in the game to accomplish the mission (intervention units). The effectiveness of coordination is measured in Level 1 because it is the first level that does not end when the mission is completed, but in all cases lasts two minutes; in case the team completes the mission before time, fires continue to appear in different places and as long as the team eliminates them, they continue earning points and money.

The adaptability indicator seeks to measure the team's ability to respond to an unexpected event, i.e. a new fire that appears after the start of the game. In this experiment the adaptability was measured at Level 5 since it is the first level in which time does not end once the mission is completed, in addition there are more than 3 fires in different areas. Adaptability was calculated by comparing the team's score 30 seconds before the discovery of the second fire and 30 seconds after the second fire. As the teams will be aware of the first fire (although they have to find their location), the discovery of the second fire represents the unexpected event of interest in this experiment. The formula for adaptability is as follows:

\section{Adaptability: $\frac{\text { score after unexpected event }}{\text { score before }+ \text { score after unexpected event }} \div 0,5$}

An adaptability rating above 1 means that the score after the unexpected event is greater than the score before the unexpected event. This formula was used in order to prevent scores of 0 , or equal scores before and after the unexpected event, from creating false missing data.

\section{RESULTS}

From the analysis of the recordings of the game performed by the different teams, it is possible to have access to a great amount of information, not only to the data related to the calculations of the proposed metrics, but also to the interaction dynamics in the 
teams: active participation of the members, fulfillment of the assigned or defined role for each team member, focus on the mission of each level, level reached, exchange of ideas among the team members and acquisition of resources.

For each team, performance indicators, coordination effectiveness and adaptability to the unexpected event were calculated. The results are presented in Table 3.

Table 3. Results obtained by the teams [28]

\begin{tabular}{|c|c|c|c|c|c|c|c|c|}
\hline & \multicolumn{8}{|c|}{ Traditional organization } \\
\hline & 1 & 2 & 3 & 4 & 5 & 6 & 7 & average \\
\hline Performance & 2 & 0.66 & 1.33 & 0.6 & 2.66 & 0.6 & 1.33 & 1.3 \\
\hline \multicolumn{9}{|l|}{ Coordination } \\
\hline $\begin{array}{l}\text { Effectiveness } \\
\text { (score) }\end{array}$ & 980 & 320 & 1018 & 1150 & 1210 & 1470 & 1180 & 1046.9 \\
\hline \multicolumn{9}{|l|}{ Coordination } \\
\hline $\begin{array}{l}\text { Effectiveness } \\
\text { (money) }\end{array}$ & 1680 & 1210 & 1990 & 2260 & 2420 & 2480 & 2290 & 2047.1 \\
\hline \multirow[t]{3}{*}{ Adaptability } & 1.33 & $\begin{array}{l}\text { They do } \\
\text { not reach } \\
\text { the level of } \\
\text { study }\end{array}$ & $\begin{array}{l}\text { They do } \\
\text { not reach } \\
\text { the level of } \\
\text { study }\end{array}$ & $\begin{array}{l}\text { They do } \\
\text { not reach } \\
\text { the level of } \\
\text { study }\end{array}$ & 1.64 & $\begin{array}{l}\text { They do } \\
\text { not reach } \\
\text { the level of } \\
\text { study }\end{array}$ & $\begin{array}{l}\text { They do } \\
\text { not reach } \\
\text { the level of } \\
\text { study }\end{array}$ & 0.4 \\
\hline & \multicolumn{8}{|c|}{ Organization with collective intelligence inductors } \\
\hline & 1 & 2 & 3 & 4 & 5 & 6 & 7 & average \\
\hline Performance & 2.6 & 1.3 & 2 & 2.66 & 2 & 2.66 & 2 & 2.2 \\
\hline \multicolumn{9}{|l|}{ Coordination } \\
\hline $\begin{array}{l}\text { Effectiveness } \\
\text { (score) }\end{array}$ & 890 & 470 & 1050 & 2180 & 2590 & 2270 & 2710 & 1737.1 \\
\hline \multicolumn{9}{|l|}{ Coordination } \\
\hline $\begin{array}{l}\text { Effectiveness } \\
\text { (money) }\end{array}$ & 1860 & 1480 & 2020 & 3180 & 3820 & 3320 & 3980 & 2808.6 \\
\hline Adaptability & 1.45 & $\begin{array}{l}\text { They do } \\
\text { not reach } \\
\text { the level of } \\
\text { study }\end{array}$ & $\begin{array}{l}\text { They do } \\
\text { not reach } \\
\text { the level of } \\
\text { study }\end{array}$ & 1.21 & 0.75 & 1.12 & 0.79 & 0.8 \\
\hline
\end{tabular}

Source: own work

As can be seen in Table 3, the teams whose structure incorporates inductors that facilitate collective intelligence present, on average, greater performance, coordination effectiveness and adaptability to the unexpected event (a second fire not foreseen by the team). It is to be noted that the Level 5 of the game required for measuring adaptability is only reached by two teams with traditional structure and in 5 teams with the structure that facilitate the $\mathrm{Cl}$.

Regarding the team dynamics, it is evident that in teams with a traditional structure there is a clear orientation to the fulfillment of the mission of each level; however, it is the head of planning who, during the development of the whole experiment, makes 
the decisions about the game: which fires to put out, resources to use, commands to execute. The other members for a large percentage of the time are silent and there is no exchange of ideas regarding the strategy to follow nor is there evidence of the fulfillment of the assigned role. Additionally, only four of the teams acquire new resources to fulfill the mission.

On the other hand, in the teams with inductors that enables collective intelligence, there is also a clear orientation to the fulfillment of the mission of each level. However, there is greater participation of the members, there are high exchanges of ideas regarding the location of the fires, scarce resources, possibility of acquiring new resources, people, houses or farms at risk; this information is used in most cases by the head of planning to execute the commands. With respect to roles, all teams follow the roles suggested by the research team, and it is each member who decides which role he or she wants to play. Additionally, only one of the teams does not acquire new resources for the fulfillment of the mission.

\section{DISCUSSION AND CONCLUSIONS}

The purpose of this article was to compare the response of different teams organized through two types of structures, one hierarchical and the other characterized by the presence of inductors that enables collective intelligence, in the presence of sudden and unexpected events. The generated results show that the teams that have a structure with inductors that facilitate the $\mathrm{Cl}$ leads to greater-than-average performance, effectiveness of coordination and adaptability, as well as better dynamics of interaction between the members. In fact, in these teams they present higher levels of interaction, information flow and activity among the participants, which is reflected both in the number of interventions and in the use of the resources that the game offers to increase the ability to fulfill the mission.

The higher levels of performance exhibited by teams with structures that facilitate $\mathrm{Cl}$, can be explained through the law of required variety proposed by Ahsby "only variety absorbs variety". That is to say, as the team increases interactions, the use of the information that each one of the members has and perceives of the game increases, and therefore the team as a whole has a greater capacity to deal with the complexity of the game (unexpected fires, affected people, exhaustion of resources, etc.). In this way, the increased complexity of the team allows to absorb more complexity from the environment. This is in contrast to what happens in teams with a hierarchical structure, in which complexity is reduced by the determinism induced in the selection of members and assignment of roles by the research team. 
The increase of complexity that gives the team the application of $\mathrm{Cl}$ inducers could be a predictor of better performance in environments of increasing complexity, in contrast to teams that have structures that reduce their complexity, such as the case of the hierarchical structure. The environments of increasing complexity are characterized by the continuous gain and generation of information, which translates into the appearance of emerging behaviors difficult to predict and control. Globalization and technological development have created the conditions for the environments in which human social systems are immersed to become more complex. This highlights the limited relevance of approaches, models and structures that reduce complexity.

Figure 4 shows the complexity of the team and the environment increasing over time and allows us to visualize the impact of reducing the complexity of the team in an environment of increasing complexity.





Organization

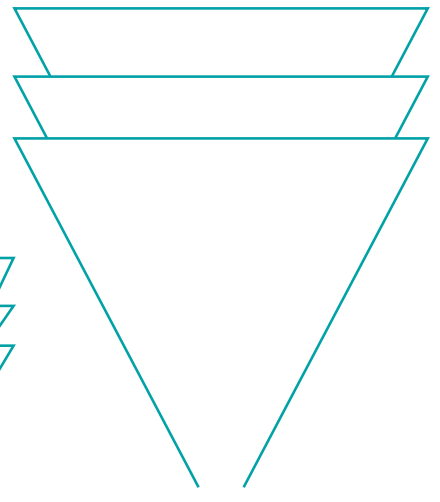

Environment

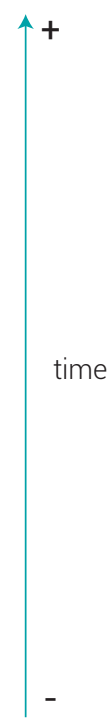

ime

Figure 4. Increasing complexity of the environment and organization over time [36] Source: own work

In this sense, the importance of introducing inductors in the structure of the team to stimulate its complexity can be highlighted. The present research emphasized the ease of interaction between agents, distributed control and diversity, from simple mechanisms such as taking advantage of the affiliation ties between the parties, visualization of all the information generated to the team and autonomy in the definition and assignment of roles; however, other mechanisms could be projected such as creating and fostering formal and informal spaces that stimulate interaction, 
the use of technological platforms, increasing the experience of the participants in the game, informing about possible strategies to follow, among other mechanisms; aspects that enable projection of bigger spaces for research in terms of the increase of the structural complexity in the performance of the teams and for extension of the company performance.

It is also possible to identify areas of research regarding the significance of diversity in team members. The above, since it could be argued that in the absence of strong affiliation ties among team members, their level of diversity is greater [3]; affiliation requires certain levels of homogeneity (tastes, preferences, hobbies, etc.). However, the results of the present experiment allow us to project research spaces regarding the degree of diversity required in the teams to improve their performance. This is because the team that took advantage of the affiliation links between the members, and therefore with less diversity in comparison with the team with hierarchical structures, had better performance.

The complexity of the teams by means of the structure can be a predictor of better performances in highly complex environments. However, it is interesting to analyze whether the accelerated increase in complexity may trigger chaotic behaviors in the team and therefore affect performance.

\section{REFERENCES}

[1] S. Papert, "Desafío a la mente. Computadoras y educación," vol. 5, Buenos Aires: Galápago, 1982.pp. 158-163.

[2] T. W. Malone, "What is collective intelligence and what will we do about it? Collective intelligence: creating a prosperous world at peace," 1st ed. 2008. pp 65-74.

[3] A. Camacho, M. G. Merayo, and M. Núñez, "Collective intelligence and databases in eHealth: A survey," J. Intell. Fuzzy Syst., vol. 32, no. 2, Universidad Complutense de Madrid, Spain, 2017. pp. 1485-1496 [Online]. Available: https://pdfs.semanticscholar.org/447a/6a4870 783 56123418a7c4bdda419f9865d68.pdf.

[4] G. Hernández-Chan, A. Rodríguez-González, G. Alor-Hernández, et al., "Knowledge Acquisition for Medical Diagnosis Using Collective Intelligence," J Med Syst., 36, 5-9 (2012), doi: https:// doi.org/10.1007/s10916-012-9886-3

[5] G. S. Hernández, E. E. Ceh, J. L. Sanchez, M. Villanueva, A. Rodríguez, and Y. Pérez, "Collective intelligence in medical diagnosis systems: A case study," Comput. Biol. Med., vol. 74, pp. 45-53, Jul. 2016, doi: https://doi.org /10.1016/j.compbiomed.2016.04.016 
[6] Y. Pérez, G. Alor, G. Cortes, and A. Rodríguez, "Collective intelligence as mechanism of medical diagnosis: The iPixel approach,” Expert Syst. Appl., vol. 40, no. 7, pp. 2726-2737, 2013, doi: http://dx.doi.org /10.1016 / j.eswa.2012.11.020

[7] A. Tacchella et al., "Collaboration between a human group and artificial intelligence can improve prediction of multiple sclerosis course: a proof-of-principle study," F1000 Research, vol. 6, no. 0, p. 2172, Dec. 2017, doi: http://dx.doi.org /10.12688/f1000research.13114.

[8] B. Brehmer, Some reflections on microworld research. In S. G. Schifflet, L. R. Elliott, E. Salas, and M. D. Coovert (Eds.), "Scaled worlds: Development, validation and applications" (pp. 2236). Aldershot, England: Ashgate, 2004.

[9] Jobidon, et al "Adaptability in Crisis Management: The Role of Organizational Structure". Canada, 2010.pp 5-12

[10] J.B. Smith, "Collective Intelligence in Computer-Based Collaboration". The University of North Carolina. 1994. [Online]. Available: http://www.cs.unc.edu/Research/jbsArchive/docs/ CollectiveIntelligence/CollectiveIntelligenceFrontMatter.pdf pp. 176-201

[11] P. Levy. "Collective Intelligence: Mankind's Emerging World in Cyberspace". United States. 1997. [Online]. Available: https://dl.acm.org/doi/book/10.5555/550283

[12] L. Longo, P. Dondio, S. Barrett, "Enhancing Social Search: A Computational Collective Intelligence Model of Behavioural Traits, Trust and Time". 2010, pp 48-53, doi: http://dx.doi. org/10.1007/978-3-642-17155-0_3

[13] M. Newman, A-L. Barabási, and D. J. Watts, (Eds.). "The Structure and dynamics of networks". Princeton University Press, 2006.pp 415-433

[14] M. Vidal, M. E. Cusick, A-L. Barabasi. "Interactome Networks and Human Disease". (pp. 986998). 2011 [Online]. Available: https://www.sciencedirect.com/science/article/pii/S0092867 411001309)

[15] J. R. Rodríguez., y V. Yanes, "La incertidumbre percibida del entorno como condicionante del riesgo estratégico asumido por el decisor," Cuadernos de Economía y Dirección de la Empresa, vol. no. 25, 2005, pp.5-28. [Online]. Available: https://www.redalyc.org/articulo. oa?id=80717237001

[16] T. Fuentes, M. Luna, "Analysis of three planning models under five principles of complex thinking," vol 5, no 2. pp 2-16, 201. [Online]. Available: https://dialnet.unirioja.es/servlet/ articulo?codigo $=3895231$ 
[17] D. Rincón, J. Valdes, L. Bohórquez, "Collective Intelligence for Decision-Making in Complex Environments: Literature Review," In: Iliadis L., Maglogiannis I., Plagianakos V. (eds) Artificial Intelligence Applications and Innovations. AIAI 2018. IFIP Advances in Information and Communication Technology, vol 519. Springer, Cham, doi: https://doi.org/10.1007/978-3 -319-92007-8_40

[18] Singh, Vivek\& Singh, Garima \& Pande, Suparna, "Emergence, Self-Organization and Collective Intelligence -- Modeling the Dynamics of Complex Collectives," in Social and Organizational Settings. Proceedings - UKSim 15th International Conference on Computer Modelling and Simulation, UKSim 2013. 182-189. 10.1109/UKSim.2013.77.

[19] Figure 1. Made by the authors.

[20] Figure 2. Made by the authors.

[21] Figure 3. Made by the authors.

[22] Rappi 2019. p.1 [Online]. Available: https://www.rappi.com/jobs/teams

[23] Vueltap 2019. p.1 [Online]. Available: https://servicios.vueltap.co/blog/

[24] Waze 2019. p.1 [Online]. Available: https://medium.com/waze

[25] Glovo 2019. p.1 [Online]. Available: https://glovoapp.com/es/faq

[26] Table 1. Made by the authors.

[27] Table 2. Made by the authors.

[28] Table 3. Made by the authors.

[29] C.E. Toca Torres, "Swarm intelligence: approach to the analysis of networks" 2014, vol 30, pp 262-266, doi: https://doi.org/10.1016/j.estger.2014.01.014

[30] J.F. Zuluaga, "La gestión crítica del conocimiento y la inteligencia colectiva y su relación con el desarrollo social," vol. 11, no. 2, 2015, pp. 180-184., doi: https://doi.org/10.18041/ entramado.2015v11n1.22231\%20

[31] A. Grasso and G. Convertino, "Collective intelligence in organizations: Tools and studies," Computer Supported Cooperative Work (CSCW), vol. 21, no. 4-5, pp. 357-369, doi: 10.1007/ s10606-012-9165-3 
[32] G. Convertino., A. Grasso., G. De Michelis, D.R. Millen, and E. H. Chi, "Clorg: Collective intelligence in organizations," In Proceedings of the 16th ACM international conference on Supporting group work. 2010. pp.355-358, doi: https://doi.org/10.1145/1880071.1880149

[33] S. Suran, V. Pattanaik, and D. Draheim, "Frameworks for Collective Intelligence: A Systematic Literature Review". ACM Computing Surveys (CSUR) 2020, 53(1), pp. 1-36, doi: https://doi. org/10.1145/3368986

[34] A. Nagalakshmi and S. Joglekar, "Collective Intelligence Applications -- Algorithms and Visualization," 2011 Second International Conference on Emerging Applications of Information Technology, Kolkata, 2011, pp. 25-30, doi: 10.1109/EAIT.2011.82.

[35] L. Huang, H. Zhang, G. Chen, Y. Liu and D. Li, "From turing machine intelligence to collective intelligence," 2012 IEEE 2nd International Conference on Cloud Computing and Intelligence Systems, Hangzhou, 2012, pp. 1171-1177, doi: 10.1109/CCIS.2012.6664568.

[36] C. Merino M. "Inteligencia e identidad colectiva en las organizaciones" 2016. pp 15-19.

[37] K. Cepeda-Susatama, K. Durango-Ruiz, L. Bohórquez- Arévalo, "Modelación y simulación en agentes como alternativa para el estudio de las organizaciones empresariales," Ingeniería Solidaria, vol. 13, n. o 22, mayo de 2017, pp. 103-119, doi: http://dx.doi.org/10.16925/ in.v13i22.1838

[38] L. Y. Gualdrón-Prieto, J. M. Acosta-Romero y L. E. Bohórquez-Arévalo, "Estructuras organizaciones y adaptación a las condiciones cambiantes del entorno: retos e implicaciones," Ingeniería Solidaria, vol. 13, no. 23, pp. 106-122, Sept. 2017, doi: https://doi.org/10.16925/ in.v23i13.1983

[39] E. de Ávila y A. Díaz, "Articulación del sistema ferroviario con los puertos marítimos y fluviales colombianos como alternativa estratégica para mejorar la competitividad internacional," Conocimiento Global, vol. 2, no. 1, pp. 69-73. 2017. [Online]. Available: http:// conocimientoglobal.org/revista/index.php/cglobal/article/view/18

[40] A. Castro, A. Caballero y J. Palacios, "La competitividad potencial del puerto de Cartagena: una oportunidad para el comercio exterior," Aglala, vol. 10, no. 2, pp. 111-121. 2019. [Online]. Available: http://revistas.curnvirtual.edu.co/index.php/aglala/article/view/1180

[41] A. Castro, "El coaching como puntos de fortalecimiento del profesionalismo del docente," Enfoque Disciplinario, vol. 2, no. 1, pp. 15-22. 2017. [Online]. Available: http://enfoquedisciplinario.org/revista/index.php/enfoque/article/view/14 
[42] A. C. Lemus Pinto, C. A. Garzón Sogamoso, y G. M. Tarazona Bermúdez, "Tic en gestión de la cadena de suministro bogotana," Vis. Electron., vol. 10, no. 2, pp. 195-202, 2016.

[43] C. H. Caicedo y A. Smida, "Intensidad informacional para la longitudinalidad asistencial en sistemas de salud," Visión electrónica, vol. 10, no. 1, pp. 83-95, jun. 2016, doi: https://doi. org/10.14483/22484728.11612

[44] J. F. Herrera-Cubides, P. A. Gaona-García, C. E. Montenegro-Marín, S. Sánchez-Alonso, y D. Martin-Moncunill, "Abstraction of linked data's world," Visión electrónica, vol. 13, no. 1, pp. 57-74, feb. 2019, doi https://doi.org/10.14483/22484728.14397 